\title{
Factors Affecting Sustainable Tourism Development in Ba Ria-Vung Tau, Vietnam
}

\author{
Dong Van VU' ${ }^{1}$, Ghi Nha TRAN ${ }^{2}$, Hien Thi Thu NGUYEN ${ }^{3}$, Cong Van NGUYEN ${ }^{4}$
}

Received: July 02, 2020 Revised: July 19, 2020 Accepted: August 10, 2020

\begin{abstract}
Sustainable development - including tourism development - is the general trend of all economies. With the orientation to build and develop the tourism industry into a key economic sector and become a tourist center of the Southeast region, Vietnam, Ba Ria-Vung Tau Province is demanding a proper, rational, development policy, while ensuring the development and exploitation of immediate natural advantages, and ensuring long-term sustainable development. The objective of this study is to examine the factors and their trends in sustainable tourism development in Ba Ria-Vung Tau Province, Vietnam. Methods used include descriptive statistical analysis, exploratory factor analysis and regression analysis. Data was collected from the results of a survey of 550 domestic and foreign tourists visiting Ba Ria-Vung Tau. With the help of SPSS statistical software, 12 groups of factors affecting sustainable development were identified including: economy, society, environment, humanistic tourism resources, natural tourism resources, tourism human resources, tourism products and service, tourism quality, infrastructure, technical facilities, governmental management and group of criteria to evaluate sustainable tourism development. The research results show that there are four groups of factors that significantly affect sustainable tourism development in Ba Ria-Vung Tau. These are groups of factors: Society, Environment, Tourism products and service, and Technical facilities.
\end{abstract}

Keywords: Environmental Factors, Social Factors, Sustainable Tourism Development, Tourism Products, Service Factors

JEL Classification Code: Q01, R11, Z32

\section{Introduction}

Tourism has always been one of the largest economic sectors in the world and an important one for many countries. However, with the development process, the degrading effect of tourism has become a major concern for all countries and needs to be addressed quickly. Therefore, sustainable development - including tourism development -

${ }^{1}$ First Author. Ba Ria - Vung Tau University, Vietnam.

Email: vuvandong72@gmail.com

${ }^{2}$ Ba Ria - Vung Tau University, Vietnam.

Email: writetran88@gmail.com

${ }^{3}$ Industrial University of Ho Chi Minh City (IUH), Vietnam. Email: nguyenthuhien@iuh.edu.vn

${ }^{4}$ Corresponding Author. Professor, Industrial University of Ho Chi

Minh City (IUH), Vietnam [Postal Address: 12 Nguyen Van Bao

Street, Ward 4, Go Vap District, Ho Chi Minh City, 727900, Vietnam]

Email: anhcongtuan@gmail.com

(c) Copyright: The Author(s)

This is an Open Access article distributed under the terms of the Creative Commons Attribution Non-Commercial License (https://creativecommons.org/licenses/by-nc/4.0/) which permits unrestricted non-commercial use, distribution, and reproduction in any medium, provided the original work is properly cited. is a requirement and a development goal of every country and every locality because it ensures effective and long-term development.

Ba Ria-Vung Tau Province of Vietnam is a place where converges many favorable conditions for tourism development, especially the rich and diverse potential of marine tourism resources including special tourism resources such as Long Hai beach, Con Dao National Park with revolutionary historical relics of Con Dao prison, Binh Chau-Phuoc Buu Nature Reserve with hot mineral resources in Binh Chau, etc. With such tourism resources, Ba Ria-Vung Tau has long become an attractive destination for domestic and foreign tourists. However, the tourism industry in $\mathrm{Ba}$ Ria-Vung Tau has many unsustainable signs.

Sustainable development, not only focuses on development in all aspects of the present, but also ensures continuous development in the future. Each country relies on specific economic, social, political, geographical, and cultural characteristics to develop appropriate sustainable development strategy. Sustainable development must take into account the current status of exploitation of renewable and non-renewable resources, to favorable conditions, 
benefits and difficulties in organizing short-term and longterm action plans (IUCN-UNEP-WWF, 1980). Sustainable development satisfies the needs of the present, but does not reduce the ability to satisfy the needs of future generations (United Nations World Commission on Environment and Development, 1987). Thus, if an activity is sustainable, it can theoretically be done forever. Sustainable development must be based on economic, social and environmental sustainability.

Sustainable tourism development is closely related to sustainable development and is part of sustainable development. Both are closely related to the environment and have reciprocal effects. Good environmental protection will promote growth. Conversely, if development declines, environmental protection will fail. Therefore, tourism development must go hand in hand with resource protection, not negatively affecting the environment, i.e., sustainable tourism development. Sustainable tourism must become a development trend of the tourism industry and sustainable tourism, not only plays a role in protecting the environment, but also plays a role in promoting economic development and social justice, in close association with sustainable development.

Machado (2003) said that sustainable tourism is a form of tourism that meets the current needs of tourists, the tourism industry and host communities today without compromising the ability of future generations to meet their own needs. Tourism is economically efficient, but does not destroy the resources that the future of tourism will depend on, especially the physical environment and social structure of the host community. In the current period, sustainable tourism development requires the development of highquality tourism products that are able to attract and meet the increasing demands of tourists, but without causing harm to the natural environment and indigenous culture, and must be responsible for the conservation and development of natural resources and the environment. Sustainable tourism products are products that are built in accordance with the environment, community and cultures, so that they will bring certain benefits rather than threats to tourism development (UNEP, 2003).

\section{Literature Review}

\subsection{Studies on Sustainable Tourism Development}

Sustainable tourism was officially recognized in early 1995 when the Sustainable Tourism Regulation was adopted (Charter for Sustainable Tourism, 1995). Accordingly, tourism development must be based on sustainability criteria, which means that it must be able to sustain ecologically in the long run, as well as economic and ethical and social justice. Tourism should contribute to sustainable development and integration with the natural, cultural and human environment, and consider its impact on cultural heritage and traditional elements, activities and motivation of each local community. Although tourism is considered one of the largest industries in the world, the negative effects of tourism have become a major concern and need to be addressed quickly. Therefore, sustainable tourism has emerged with the aim of reducing the negative impact of tourism, balancing environmental protection, maintaining cultural integrity, establishing social justice and promoting benefits economically, meeting the needs of the host community for improved living standards both in the short and long term (Zolfani, Sedaghat, Maknoon, \& Zavadskas, 2015).

In terms of sustainable development, WCED (1987) argues that sustainable development is not a fixed harmonious state, but rather a dynamic process of change, all harmonizing and enhancing potential, current and future abilities to meet the needs and aspirations of everyone. Sustainable tourism development involving the principle of intragenerational and intergenerational equity (World Bank, 1999). Sustainable tourism development both promotes the management of all resources in a way that economic, social and aesthetic needs can be met, while maintaining cultural integrity and essential ecological processes, biological diversity and life support systems (Liu, 2003). Sustainable tourism development means the optimal use of social, natural, cultural and financial resources to develop the country on a fair and self-sustaining basis to provide a unique experience for visitors and improve the quality of life through partnerships between local governments, the private sector and the community (Rukuižienè, 2014). On the other hand, sustainable tourism development not only aims to meet the current needs of tourists and the host area, but it must also focus on protecting and enhancing opportunities for the future. Sustainable tourism development impacts the adaptation and resilience of rural communities with tourism activities. Social resilience will increase in communities with access to information and new knowledge dissemination (Setiawan, Rijanta, \& Baiquni, 2017).

Mamhoori (2015) found that tourism is the fastest growing industry in the world, creating a lot of jobs, national income; especially, tourism creates the source of the third-largest forex income in the world. The growth of tourists and the booming development of this industry have created significant impacts on natural resources, consumption patterns, pollution and social systems. From there, the scholar stressed the need for more responsible sectoral planning and management to minimize the negative impact of tourism and maximize the potential of tourism for sustainable development. Mamhoori and Nasim (2013) argue that there is no widely-accepted definition of sustainable tourism, but all the definitions have some similarities. Accordingly, sustainable tourism brings quality experiences for visitors while improving the quality 
of life of the host community and protecting the quality of the environment. Sustainable tourism ensures the continuity of natural resources based on the culture of the host community with satisfying experiences for visitors. Sustainable tourism is balancing the needs of the tourism industry, environmental advocates and local communities. Sustainable tourism also emphasizes goals and mutual cooperation between visitors, host communities and destinations.

\subsection{Studies on the Factors Affecting Sustainable Tourism Development}

Making tourism more sustainable is not only to control and manage the negative impacts of the industry, but sustainable tourism must bring economic and social benefits to the local community and raise awareness and support for environmental conservation (UNEP \& WTO, 2005). When considering the model of sustainable tourism development, Maftuhah, and Wirjodirdjo (1977) realized that there are five main pillars to support sustainable tourism - tourism attraction, access, facilities, support, and participation community - and three sustainability aspects (social-culture, economy, and environment). To ensure sustainable tourism development, Angelevska-Najdeska, and Rakicevik (2012) believe that a sustainable tourism development plan is needed and this is the only way to succeed.

Mamhoori and Nasim (2013) find that although tourism is the second largest industry in India, there does not seem to be any concerted effort from Indian tour operators. In particular, managers of tour operators need to have high knowledge and expertise to be able to make appropriate decisions to attract tourists and make the Indian tourism industry develop sustainably. Studying the elements of sustainable tourism development, Vidishcheva, and Bryukhanova (2017) recognize that establishing and implementing sustainable development programs is a long and costly process, affected by factors of the internal and external environment. These include factors such as constraints (capital flows and support for the air-conditioned complex; seasonal management efficiency, level of e-commerce use in tourism; economic stagnation, savings system energy and water; ecological issues) and stimulus (major events; the basis, overall growth of domestic tourism, infrastructure development, government marketing and investment policies, international cooperation to achieve ecological standards).

Regarding the economic and environmental impact of mass tourism on regional tourism destinations in Indonesia, Lee and Syah (2018) realized that there is a long-term equilibrium relationship between tourism receipts, environmental degradation and economic growth. The research results also show that tourism growth and the growth of agricultural land are positively associated with the increase in total short-term output. Environmental degradation increases a lot in the inverse of the model, ultimately the negative impact on the environment.

Kattiyapornpong, Ditta-Apichai, Kanjanasilanon, and Siriyota (2018) recognize the perceptions of stakeholders and local leaders and policymakers that have a strong impact on sustainable tourism development in the local community. Research by Fabić and Jurdana (2018) on local tourism development planning in towns in Croatian coastal districts show that local authorities are not fully aware of their role in planning and promote sustainable development in destinations. Local authorities at all destinations did not conduct the types of activities that promoted sustainable development and addressed the problems they encountered when implementing and implementing these activities. The study also shows that local governments have no plans to promote sustainable development, they do not identify and do not use indicators to measure sustainable growth and they pay little attention to ecological sustainability, cultural, economic and social.

To test the model of community empowerment to develop sustainable tourism villages in Indonesia, Purnomo, Rahayu, Riani, Suminah, and Udin (2019) have applied qualitative method on the basis of data collected through interviews, observations and focus group discussions. The research results show that sustainable tourism development is influenced by leadership, innovation, cooperation and village governance, especially community empowerment. Because without community empowerment, without community participation and awareness to establish rural tourism, village tourism activities will not develop sustainably. The consequences will lead to community denial, the conflict between citizens in the use of land income, lack of transparency in financial management and underdevelopment of rural tourism activities in improve community welfare.

By examining documents related to sustainable tourism and using qualitative methods, Vuong and Rajagopal (2019) have identified three main factors affecting sustainable tourism in Vietnam in a new era - social, economic and environmental. Their research also shows that, when planning a tourism business development strategy, there must be a long-term vision for tourism and its benefits and consequences. Tourism should be developed professionally and sustainably on the basis of protecting cultural beauty, tourist destination and researching reasonable prices for tourists. Regarding sustainable tourism development in Vietnam, Vu, Nguyen, Nguyen and Le (2020) have identified seven factors that have influence. The impact factors are sorted by the level of diminishing influence: social participation, state management capacity, quality of tourism services, quality of tourism human resources, infrastructure development, material tourism facilities, and tourism resources. 
The study of issues caused by the state of overtourism influences the quality of life of people and their perceptions of redundancy by exploring factors related to future policy impacts. Kim, Choi, Chang and Lee (2020) realize that the excess of tourism caused by tourists and trips that exceed the capacity of tourist destinations are a threat to the quality of life of residents at destinations, reduce quality of tourism, quality of life of local residents and destruction of cultural heritage, threatens environmental and limited economic benefits for local people.

Studying factors affecting sustainable tourism, Vodenska (2020) found that social factors had the highest positive impact, followed by environmental factors and finally economic factors. His research also shows the inverse relationship between the type of seasonal tourism at the destination, between the level of tourism development at the destination, and between the stage of tourism development at the destination and the level of sustainable development of the destination. The more diverse and plentiful the type of seasonal tourism, the higher the level of tourism development; the higher the stage of tourism development at the destination, the lower the level of sustainable development at the destination and vice versa.

\section{Research Methods, Process and Model}

\subsection{Research Methods and Process}

The research uses methods such as descriptive statistical analysis, exploratory factor analysis and regression analysis. The statistical analysis describes the properties of the objects being surveyed. Exploratory factor analysis (EFA) collects estimated parameters and adjusts the research model by examining the relationships among the component groups of elements and can redefine the variables identified designated for the element; the scale and reliability test. Regression analysis to find the best model to determine the impact of the factors on sustainable tourism development on the basis of using model, correlation and multicollinearity test acceptable level depending on the model.

The specific research steps are as follows:

- Questionnaire design:

From the results of qualitative research and information needs for research objectives, the questionnaire related to the factors affecting sustainable tourism development is designed with 12 elements and 99 specific criteria (observed variables) to measure and assess the situation. Comment on factors affecting sustainable tourism development with the 5-point Likert scale - 1-Strongly disagree; 2-Disagree; 3-Temporarily accepted; 4-Agree; 5-Totally agree.

The questionnaire was calibrated through a test survey. The number of participants in the pilot survey was 14 , selected samples of those who had access to tourism organizations (through research, use, management, beneficiary, visits, exposure to travel services) and have experience in designing survey questionnaires with large sample sizes. The questionnaire uses both Vietnamese and English languages and paper and word document (fill in the form and return it to the investigator to update data)

\section{- Data coding:}

Data coding is designed from the stage of designing online votes to information providers and data updaters. The scale data is encoded by the sequence number shown in the questionnaire. Personal information is coded at the time of updating online votes, according to the date and time of updating information, survey papers in word documents updated by email address of the sender. At the same time, the observed variables of these are coded according to the specific matrix method.

\section{- Quantitative research sample:}

The total number of questionnaires issued was 600 , collecting 569 votes. The survey comes from four locations in Ba Ria-Vung Tau Province: Vung Tau City, Long Hai Town, Binh Chau Tourism Area, Con Dao Islands and a few other locations. The object of the survey focused on those who have used and researched sustainable tourism development activities at institutes, schools, businesses, tourism organizations and domestic and international tourists in Ba Ria-Vung Tau.

Data collection is carried out by collaborative groups at institutes/schools and the Department of Culture, Sports and Tourism. The survey was conducted through direct interviews with tourists, through fieldwork and indirectly via electronic email system to transfer the link of the online questionnaire and attach the questionnaire for members of the surveyed subjects. After collecting a sufficient number of questionnaires, the data is cleaned by checking the answers on the questionnaire and selecting only those questionnaires with enough information as required. At the same time, the data is continued to be cleaned with the Scatter graph tool to eliminate data discrepancies. Questions are handled with the help of SPSS software. The remaining 550 votes met the requirements (see Table 1).

\section{- Exploratory factor analysis (EFA):}

From the observed measurement variables impacting on sustainable tourism development in Ba Ria-Vung Tau, the study conducted exploratory factor analysis (EFA) to minimize the interdependent measurement variables into a smaller set of variables so they make more sense, but still contain most of the original set's informational content. These are factors affecting the sustainable development of Ba Ria-Vung Tau according to the assessments of tourists, the community, businesses and state management levels on tourism. In this study, there are no regional or national impact factors such as changes in demand, interest rates, and the stability of the tourism development environment in $\mathrm{Ba}$ Ria-Vung Tau or other elements of irregular nature. 
Table 1: Visitor characteristics surveyed

\begin{tabular}{|c|c|c|c|}
\hline \multicolumn{2}{|c|}{ Particulars (Characteristics \& Distribution) } & \multirow{2}{*}{$\begin{array}{c}\text { Frequency (people) } \\
203\end{array}$} & \multirow{2}{*}{$\begin{array}{c}\text { Percentage (\%) } \\
36.9 \\
\end{array}$} \\
\hline 1. Survey area & Vung Tau & & \\
\hline & Long Hai & 80 & 14.5 \\
\hline & Binh Chau & 166 & 30.3 \\
\hline & Con Dao & 97 & 17.6 \\
\hline & Other & 4 & 0.7 \\
\hline & Grand Total & 550 & 100.0 \\
\hline \multirow[t]{8}{*}{ 2. Occupation } & International experts & 94 & 17.1 \\
\hline & Researchers & 56 & 10.2 \\
\hline & State management & 180 & 32.7 \\
\hline & Company leadership & 45 & 8.2 \\
\hline & Business staff & 95 & 17.3 \\
\hline & Technical staff & 44 & 8.0 \\
\hline & Other & 36 & 6.5 \\
\hline & Grand Total & 550 & 100.0 \\
\hline \multirow[t]{3}{*}{ 3. The gender } & Male & 333 & 60.5 \\
\hline & Female & 217 & 39.5 \\
\hline & Grand Total & 550 & 100.0 \\
\hline \multirow[t]{5}{*}{ 4. Age (years) } & $35<$ & 115 & 20.9 \\
\hline & $35-45$ & 155 & 28.2 \\
\hline & $46-55$ & 135 & 24.5 \\
\hline & $>55$ & 145 & 26.4 \\
\hline & Grand Total & 550 & 100.0 \\
\hline \multirow{5}{*}{$\begin{array}{l}\text { 5. Times of visits to Ba } \\
\text { Ria - Vung Tau (times) }\end{array}$} & 1 & 118 & 21.5 \\
\hline & $2-3$ & 189 & 34.1 \\
\hline & $4-6$ & 165 & 30.0 \\
\hline & $>6$ & 78 & 14.2 \\
\hline & Grand Total & 550 & 100.0 \\
\hline \multirow[t]{4}{*}{ 6. Education } & Bachelor & 246 & 44.7 \\
\hline & Master \& PhD & 76 & 13.8 \\
\hline & Professional diploma holders and other & 228 & 41.5 \\
\hline & Grand Total & 550 & 100.0 \\
\hline \multirow{6}{*}{$\begin{array}{l}\text { 7. Monthly Income } \\
\text { (million VND) }\end{array}$} & $<9,0$ & 167 & 30.4 \\
\hline & $9,0-15,0$ & 218 & 39.6 \\
\hline & $16,0-20,0$ & 88 & 16.0 \\
\hline & $21,0-30,0$ & 32 & 5.8 \\
\hline & $>30,0$ & 45 & 8.2 \\
\hline & Grand Total & 550 & 100.0 \\
\hline
\end{tabular}




\section{- Multivariate regression analysis:}

Multivariate regression analysis is used to quantify the impact of factors affecting the sustainable tourism development of Ba Ria-Vung Tau.

\subsection{Research Model}

The research model is built on the basis of factors and observed variables affecting the sustainable development of tourism. These factors include: (1) Economic factors - EF; (2) Social factors - SF; (3) Environmental factors - ENF; (4) Natural tourism resources factors - NTR; (5) Humanistic tourism resources factors - HTR; (6) Tourism products and service factors - TPS; (7) Tourism human resources factors - THR; (8) Tourism quality factors - TQF; (9) Infrastructure element factors - IEF; (10) Technical facilities factors - TFF; (11) Factors of state management on tourism - FSM; (12) Criteria for sustainable tourism development - CST (see Figure 1 and Table 2).

The specific research model is as follows:

$$
\begin{aligned}
\mathrm{STD}= & \alpha_{1} \mathrm{EF}+\alpha_{2} \mathrm{SF}+\alpha_{3} \mathrm{ENF}+\alpha_{4} \mathrm{NTR}+\alpha_{5} \mathrm{HTR}+\alpha_{6} \text { TPS } \\
& +\alpha_{7} \text { THR }+\alpha_{8} \mathrm{TQF}+\alpha_{9} \mathrm{IEF}+\alpha_{10} \text { TFF }+\alpha_{11} \text { FSM } \\
& +\alpha_{12} \text { CST. }
\end{aligned}
$$

In which:

$\alpha 1, \alpha 2, \alpha 3, \ldots$ and $\alpha 12$ are correlation coefficients. $\varepsilon$ is error.

STD: STD is the dependent variable that reflects sustainable tourism development.

The 99 observed variables (specific criteria) of 12 specific impact factors in Table 2.

\section{Research Results and Discussion}

\subsection{Results of Survey Data Analysis}

Analysis of survey data for each factor affecting sustainable tourism development in Ba Ria-Vung Tau gives the following results:

\section{- Economical factors:}

The evaluation results of most surveyed subjects on the impact of the observation criteria of economic factors affecting sustainable tourism development activities are above average. In particular, the factors related to the price reached the lowest point (reaching 3.01/6).

\section{- Social factors:}

The survey results show that the parameters are basically average, in which the lowest evaluation point is related to the "rich tourism type" (2.80 points). This result fully reflects the true status of the influence of social factors on sustainable tourism development.

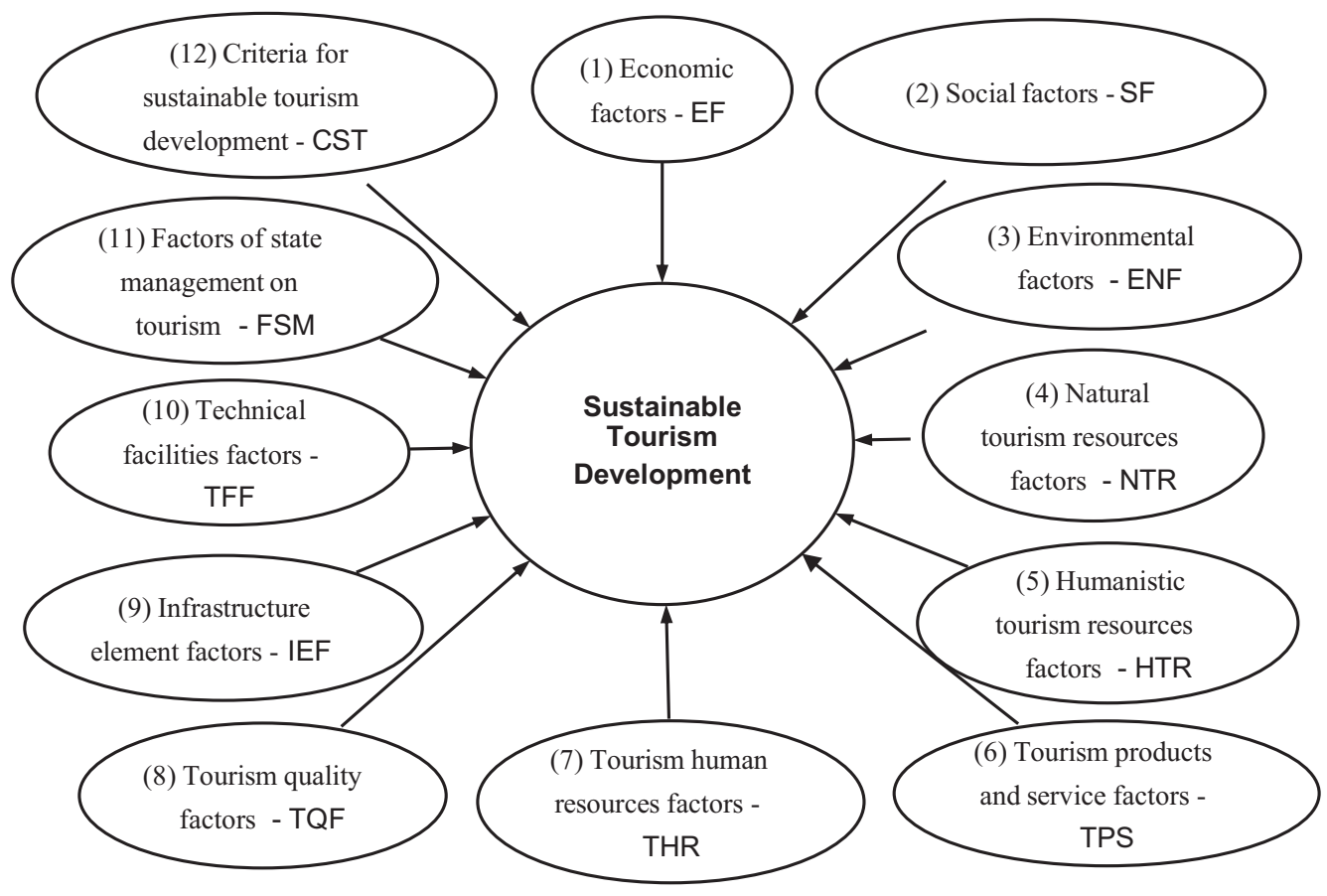

Figure 1: Overview of the research model 
Table 2: Observed variables of 12 factors affecting sustainable tourism development

\begin{tabular}{|c|c|}
\hline Impact factors & Attached observation variables \\
\hline $\begin{array}{l}\text { (1) Economic factors } \\
- \text {-EF }\end{array}$ & $\begin{array}{l}\text { (1) Economic growth for the locality, (2) Price level, (3) The level of investment for tourism, } \\
\text { (4) Tourism development policy, (5) Travel service costs, (6) Solving jobs, (7) Import-export tourism }\end{array}$ \\
\hline $\begin{array}{l}\text { (2) Social factors - } \\
\text { SF }\end{array}$ & $\begin{array}{l}\text { (1) Types of social evils, (2) The degree of begging, (3) The level of safety when traveling locally, } \\
\text { (4) Various types of travel services, (5) The level of street vendors chasing customers, (6) Gender } \\
\text { equality and racial discrimination }\end{array}$ \\
\hline $\begin{array}{l}\text { (3) Environmental } \\
\text { factors - ENF }\end{array}$ & $\begin{array}{l}\text { (1) Awareness of environmental resources protection of local people, (2) Level of risk of } \\
\text { environmental pollution, (3) Level of landslides on mountains and beaches, (4) The overload of } \\
\text { destinations, resorts, (5) The degree of infectious disease }\end{array}$ \\
\hline $\begin{array}{l}\text { (4) Natural tourism } \\
\text { resources factors - } \\
\text { NTR }\end{array}$ & $\begin{array}{l}\text { (1) Natural landscape, (2) Climate, (3) The natural environment, (4) Geographical location, (5) The } \\
\text { animals and plants, (6) Natural resources, (7) Forest resources, mountains, hills, rivers, streams, } \\
\text { lakes, seas, islands ..., (8) Natural hot springs, (9) Beautiful beach }\end{array}$ \\
\hline $\begin{array}{l}\text { (5) Humanistic } \\
\text { tourism resources } \\
\text { factors - HTR }\end{array}$ & $\begin{array}{l}\text { (1) Architectural works, (2) Historical sites, (3) Cultural works, (4) Customs and traditions, (5) } \\
\text { Religion, (6) Festival, (7) The friendliness of the people, (8) Nation, (9) Culinary arts }\end{array}$ \\
\hline $\begin{array}{l}\text { (6) Tourism products } \\
\text { and service factors } \\
\text { - TPS }\end{array}$ & $\begin{array}{l}\text { (1) The specialty of local, (2) Arts and crafts, (3) Themed tours, (4) Tourism to visit, (5) Ecotourism, } \\
\text { (6) Tourist Resort, (7) Travel conferences - seminars, (8) Adventure travel, (9) Tourism learn culture } \\
\text { - history, (10) Medical tourism, (11) Travel on the source }\end{array}$ \\
\hline $\begin{array}{l}\text { (7) Tourism human } \\
\text { resources factors - } \\
\text { THR }\end{array}$ & $\begin{array}{l}\text { (1) Management capacity, (2) Technical expertise, (3) Professional legal capacity, (4) Professional } \\
\text { competence on business, (5) The ability to meet the number of human resources, (6) Foreign } \\
\text { language ability, (7) Working style, (8) The friendliness of the service provider, (9) Communication } \\
\text { skills, (10) Professional ability, (11) The training of advanced training }\end{array}$ \\
\hline $\begin{array}{l}\text { (8) Tourism quality } \\
\text { factors - TQF }\end{array}$ & $\begin{array}{l}\text { (1) Services in tourism promotion organizations are diverse, (2) Service delivery scale of } \\
\text { organizations is very large, (3) Service prices are very low, (4) Immediate response of the service } \\
\text { is very good, (5) Very good marketing ability, (6) Access to services is easy, (7) The ability to } \\
\text { understand and meet the needs of customers very well, (8) The organizations are very reputable in } \\
\text { providing services (guarantee on time, quantity, service according to customer requirements) }\end{array}$ \\
\hline $\begin{array}{l}\text { (9) Infrastructure } \\
\text { element factors - IEF }\end{array}$ & $\begin{array}{l}\text { (1) Traffic system, (2) Communication systems, (3) Electricity distribution system, (4) Water supply } \\
\text { system, (5) Equipment for work needs, (6) Headquarters, office work, outdoor premises, (7) Park } \\
\text { area, (8) Entertainment area and relax, (9) Lodging system, hotel }\end{array}$ \\
\hline $\begin{array}{l}\text { (10) Technical } \\
\text { facilities factors - } \\
\text { TFF }\end{array}$ & $\begin{array}{l}\text { (1) Vehicles participating in traffic, (2) Supermarkets shopping goods, (3) Public sanitation system, } \\
\text { (4) Restaurant system for eating and drinking, (5) Safety warning system for visitors, (6) System of } \\
\text { signage and advertising, (7) System of other services }\end{array}$ \\
\hline $\begin{array}{l}\text { (11) Factors of state } \\
\text { management on } \\
\text { tourism - FSM }\end{array}$ & $\begin{array}{l}\text { (1) State management of tourism service prices, (2) State management of security and order, } \\
\text { (3) State management of environmental sanitation, (4) State management of tourism, (5) State } \\
\text { management of the landscape environment, (6) State management of tourism development } \\
\text { planning, (7) State management of international cooperation }\end{array}$ \\
\hline $\begin{array}{l}\text { (12) Criteria for } \\
\text { sustainable tourism } \\
\text { development - CST }\end{array}$ & $\begin{array}{l}\text { (1) Protect the tourist destination, (2) Pressure, (3) Intensity to use, (4) Social impact, (5) Degree } \\
\text { of control, (6) Waste management, (7) Planning process, (8) The critical ecosystem, (9) Travelers' } \\
\text { satisfaction, (10) Local satisfaction }\end{array}$ \\
\hline
\end{tabular}

\section{- Environmental factors:}

The survey results show that the parameters are basically below the average, in which the lowest evaluation point is related to the "level of environmental pollution risk" (1.97 points). This result fully reflects the real situation of the influence of environmental factors on sustainable tourism development.

- Natural tourism resources factors:

The survey results show that the scores evaluating the role of natural factors affecting sustainable tourism development 
are quite high. This result is consistent with the reality in $\mathrm{Ba}$ Ria-Vung Tau

\section{- Humanistic tourism resources factors:}

The survey results show that the human resources activities affecting sustainable tourism development are quite good.

- Tourism products and service factors:

Survey results on factors related to tourism products affecting sustainable tourism development in Ba Ria-Vung Tau show that tourism products are of poor quality and not yet diverse. This is also one of the important causes affecting tourists to Ba Ria-Vung Tau.

\section{- Tourism human resources factor:}

The survey result shows that, in general, the quantity and quality of human resources are not satisfactory. The strength of human resources in organizations is the technical competence, friendliness and communication skills of the employees in the organizations. But the weakest point of the organization's staff is not meeting the requirements of quantity, legal capacity as well as business.

\section{- Tourism quality factors:}

The tourism quality of Ba Ria-Vung Tau is rated at an average level compared to all other influencing factors.

- Infrastructure element factors:

The survey results show that the contents of this factor affecting the tourism development of Ba Ria-Vung Tau are evaluated at a relatively high level; in which the highest is "Communication systems" (4.39 points) and the lowest is "Entertainment area and relax" (3.19 points).

\section{- Technical facilities factors:}

The survey data shows, the average score evaluating the technical facilities of the surveyed organizations is quite good compared to all other influencing factors; in which, the highest is "Restaurant system for eating and drinking" (4.59 points) and lowest is "System of other services" (3.05 points.

\section{- Factors of state management on tourism:}

Results of the evaluation of contents under the state management of tourism in Ba Ria-Vung Tau are low, in which the highest is "State management of tourism" (2.59 points) and the lowest is "State management of tourism service prices" (2.03 points).

\section{- Criteria for sustainable tourism development:}

The results of evaluating the contents of the sustainable development factor are above average; in which, the highest is "Local satisfaction" (3.69 points) and the lowest is "Protect the tourist destination" (3.03 points).

\subsection{Assess the Reliability of the Scale}

Assessing the reliability of the scale is based on the standard Cronbach's Alpha coefficient of components from 0.8 upwards and the variables have a correlation coefficient of a total variable of 0.3 or more. With this value, the scale is considered to be a good measure and ensures a high level of reliability is achieved.

After the test, 28 observed variables were removed because they have Cronbach's Alpha if items deleted are larger than the alpha of the current Cronbach's Alpha. Results after performing analysis of Cronbach's Alpha coefficients for all scales of the research model, 12 groups of scales with good reliability corresponding to the remaining 71 observed variables were continued to be used in the Exploratory Factor Analysis.

\subsection{Explore Factor Analysis (EFA)}

The study conducts exploratory factor analysis to find groups of factors that are related to each other to form new factors, helps identify factors that are important to sustainable tourism development, and finds solutions dharma focusing on those factors.

- The coefficient of KMO coefficient (Kaiser - Meyer Olkin) is $0.932>0.5$, showing that the data used for factor analysis is perfectly appropriate.

- The observed variables correlated with each other in the whole because Bartlett's Test is 6414.91 with sig $=0.000$ $<0.050$. This confirms that the variables in the study are correlated and satisfy the conditions of factor analysis, and has rejected the hypothesis that the observed variables do not correlate with each other in the whole.

- Factor-loading factor (Factor load) is an indicator to ensure the practical meaning of factor analysis. The analysis results show that these coefficients are greater than 0.5 and there is no case that the variable simultaneously uploads both elements with the load factor close to each other, so the factors that ensure convergence maintenance and distinguish when analyzing EFA. This shows that they are considered as important and practical factors.

- The Extraction Sums of Squared Loadings is 70,399\%, showing that 12 factors have the total variance extracted at a high level $(>50 \%)$. This proves that these 12 factors explain $70,399 \%$ of the data variability. The Eigenvalues of all factors is high $(>1)$, the 12th element "Criteria for sustainable tourism development" has the lowest Eigenvalues of 1,102.

Table 3: Results of EFA analysis on the scale factors affecting sustainable tourism development (KMO and Bartlett's Test)

\begin{tabular}{|l|l|c|}
\hline \multicolumn{2}{|l|}{$\begin{array}{l}\text { Kaiser-Meyer-Olkin Measure of } \\
\text { Sampling Adequacy. }\end{array}$} & .932 \\
\hline $\begin{array}{l}\text { Bartlett's Test of } \\
\text { Sphericity }\end{array}$ & Approx. Chi-Square & 6414.915 \\
\cline { 2 - 3 } & df & 1176 \\
\cline { 2 - 3 } & Sig. & .000 \\
\hline
\end{tabular}




\subsection{Regression Analysis}

In order to have a sustainable tourism development solution in Ba Ria-Vung Tau, it is necessary to identify the factors that need to be developed first to create a basic premise for the sustainable development of the tourism industry. For that purpose, the authors conducted multiple regression analyzes with the dependent variable being tourism development activity in Ba Ria-Vung Tau (STD variable has been averaged) and independent variables (12 independent variables were detected above), in which, the regression variables are calculated as the average of the observed variables of each factor with the expected signs of all these variables are positive.

Based on the regression results, the study will identify factors that have a significant impact on sustainable tourism development in the current period to propose policies focusing on tourism industry development in $\mathrm{Ba}$ Ria-Vung Tau. The regression analysis results in Table 4 show that R2 (Adjusted R Square) is adjusted to be 0.598 and sig is $0.000(<0.005)$, so the model is suitable. It also means that $59.8 \%$ of the dependent variable (STD) is explained by the linear relationship with the independent variables included in the model, the remaining $40.2 \%$ is influenced by variables outside the model and random errors.

See the ANOVA table (Table 4) in the regression results shows that: the statistical value F of the model has Sig value. $=0.000<0.01$ shows the H0 hypothesis is completely rejected with $99 \%$ confidence. It can be concluded that the overall model with variables EF, SF, ENF, NTR, HTR, TPS, THR, TQF, IEF, TFF, FSM, CST are associated with SAT variables, and explain the change. conversion of the STD variable.
Table 5 shows that the correlation between the independent variables is less than 0.6 and the VIP magnification coefficient is less than 2 , so it can be concluded that there is no multi-collinear phenomenon.

The regression results in Table 5 also show the sig coefficient of variables SF, ENF, TPS, TFF have value $<0,021$. Therefore, the regression coefficients of these variables are statistically significant at $97.9 \%$; the regression coefficients of the remaining variables (EF, NTR, HTR, THR, TQF, IEF, FSM, CST) are not statistically significant.

Therefore, the multiple regression equation for the problem is:

$$
\mathrm{STD}=0.623 \mathrm{SF}+0.167 \mathrm{ENF}+0.104 \mathrm{TPS}+0.153 \mathrm{TFF}
$$

The results of the regression analysis show that, out of 12 factors affecting the sustainable tourism development of $\mathrm{Ba}$ Ria-Vung Tau province, only four factors have significant influence. These factors, in descending order of influence, are: SF (Social factors), ENF (Environmental factors), TFF (Technical facilities factors) and TPS (Tourism products and service factors). All four groups of factors have a positive impact on the sustainable tourism development of $\mathrm{Ba}$ Ria-Vung Tau. If the value of one of these factors or all of these four factors is increased, the sustainable tourism development of Ba Ria-Vung Tau will increase. In other words, improving any of them will increase the sustainable tourism development of Ba Ria-Vung Tau. The remaining eight groups of factors all have a sig value greater than 0.05 , which makes no sense in the model, meaning that they have no impact on the sustainable tourism development of Ba RiaVung Tau.

Table 4: Analysis results Model Summary and Anova

Model Summary ${ }^{b}$

\begin{tabular}{|c|c|c|c|c|c|c|c|c|c|c|}
\hline \multirow[b]{2}{*}{ Model } & \multirow[b]{2}{*}{$\mathbf{R}$} & \multirow{2}{*}{$\begin{array}{c}\mathbf{R} \\
\text { Square }\end{array}$} & \multirow{2}{*}{$\begin{array}{l}\text { Adjusted R } \\
\text { Square }\end{array}$} & \multirow{2}{*}{$\begin{array}{l}\text { Std. Error } \\
\text { of the } \\
\text { Estimate }\end{array}$} & \multicolumn{5}{|c|}{ Change Statistics } & \multirow{2}{*}{ Durbin-Watson } \\
\hline & & & & & $\begin{array}{c}\text { R Square } \\
\text { Change }\end{array}$ & $\begin{array}{c}F \\
\text { Change }\end{array}$ & df1 & df2 & $\begin{array}{c}\text { Sig. F } \\
\text { Change }\end{array}$ & \\
\hline 1 & $.780 a$ & .609 & .598 & .29694 & .609 & 56.692 & 12 & 437 & .000 & 1.382 \\
\hline
\end{tabular}

ANOVA $^{a}$

\begin{tabular}{|c|c|c|c|c|c|c|}
\hline \multicolumn{2}{|c|}{ Model } & Sum of Squares & df & Mean Square & $\mathbf{F}$ & Sig. \\
\hline \multirow[t]{3}{*}{1} & Regression & 69.983 & 12 & .523 & .427 & $.000^{\mathrm{b}}$ \\
\hline & Residual & 48.631 & 538 & 1.224 & & \\
\hline & Total & 97.714 & 550 & & & \\
\hline \multicolumn{7}{|c|}{ a. Dependent Variable: STD } \\
\hline \multicolumn{7}{|c|}{ b. Predictors: (Constant), EF, SF, ENF, NTR, HTR, TPS, THR, TQF, IEF, TFF, FSM, CST } \\
\hline
\end{tabular}


Table 5: Coefficients ${ }^{a}$

\begin{tabular}{|c|c|c|c|c|c|c|c|c|c|c|c|}
\hline \multirow{2}{*}{\multicolumn{2}{|c|}{ Model }} & \multicolumn{2}{|c|}{$\begin{array}{l}\text { Unstandardized } \\
\text { Coefficients }\end{array}$} & \multirow{2}{*}{$\begin{array}{c}\begin{array}{c}\text { Standardized } \\
\text { Coefficients }\end{array} \\
\text { Beta } \\
\end{array}$} & \multirow[t]{2}{*}{$\mathbf{t}$} & \multirow[t]{2}{*}{ Sig. } & \multicolumn{3}{|c|}{ Correlations } & \multicolumn{2}{|c|}{$\begin{array}{c}\text { Collinearity } \\
\text { Statistics }\end{array}$} \\
\hline & & B & Std. Error & & & & Zero-order & Partial & Part & Tolerance & VIF \\
\hline \multirow[t]{13}{*}{1} & (Constant) & .538 & .231 & & 2.234 & .022 & & & & & \\
\hline & $\mathrm{EF}$ & .041 & .033 & .045 & 1.274 & .204 & .070 & .076 & .075 & .346 & 1.274 \\
\hline & SF & .350 & .021 & .623 & 16.785 & .000 & .021 & -.064 & -.063 & .360 & 1.539 \\
\hline & ENF & .136 & .032 & .167 & 4.483 & .000 & .043 & .025 & .025 & .372 & 1.591 \\
\hline & NTR & -.062 & .049 & -.045 & -1.276 & .203 & .027 & -.016 & -.016 & .462 & 1.632 \\
\hline & HTR & .003 & .042 & -.003 & -.049 & .962 & -.042 & -.075 & -.075 & .570 & 1.305 \\
\hline & TPS & .088 & .026 & .104 & 3.065 & .001 & -.009 & -.020 & -.019 & .381 & 1.277 \\
\hline & THR & -.013 & .026 & -.017 & -.432 & .666 & .018 & .028 & .027 & .416 & 1.275 \\
\hline & TQF & -.035 & .027 & -.045 & -1.235 & .218 & .010 & .016 & .016 & .408 & 1.452 \\
\hline & IEF & -.035 & .027 & -.045 & -7.910 & .428 & .031 & .047 & .046 & .530 & 1.885 \\
\hline & TFF & .164 & .041 & .153 & -4.393 & .000 & .068 & .088 & .087 & .490 & 1.041 \\
\hline & FSM & .028 & .036 & .027 & .782 & .434 & -.004 & -.065 & -.064 & .333 & 1.005 \\
\hline & CST & -.014 & .036 & -.012 & -.339 & .735 & .017 & .030 & .030 & .406 & 1.462 \\
\hline
\end{tabular}

\section{Conclusions and Recommendations}

The results of the measurement models show that, after addition and adjustment, the scales achieved reliability and allowable values. The results also show that, out of the 12 factors affecting sustainable tourism development in Ba Ria-Vung Tau province, visitor awareness is directed to four components: SF (social factors), ENF (environment), TFF (technical basis) and TPS (Tourism products and service elements). In particular, social factors have the strongest impact on sustainable development, followed by environmental factors, technical infrastructure and finally tourism products. Based on the findings of this study, tourism companies and local authorities need to pay more attention and take appropriate measures to improve social factors. The reality in Ba Ria-Vung Tau still exists at a high level of social evils, beggars, frauds, squeezing tourist prices, too many street vendors, discrimination between rich and poor, sex and racism.

Regarding tourism environment factors, local authorities and tourism businesses should quickly have solutions to protect and manage natural resources, reduce environmental pollution, conserve biodiversity and other natural assets. Special attention should be paid to propaganda and education to raise awareness of local people on environmental resources protection, awareness of environmental pollution, erosion on mountains and beaches, about the overload of destinations, resorts, and the impact of infectious diseases.

Regarding technical infrastructure elements, it is necessary to plan, build and equip equipment in a timely, complete and synchronous manner, with a system of goods supermarkets, public sanitation systems and food restaurant systems, safety warning systems for tourists, and other service systems. These elements are currently dearly lacking in Ba Ria-Vung Tau.

Finally, tourism product and service elements in Ba RiaVung Tau province. It is easily recognized that Ba Ria-Vung Tau is currently lacking local specialties, arts and crafts, traditional craft villages, themed tours, types of ecotourism, resorts, travel conferences, seminars, adventure tours, tours to discover cultural tourism - historical, health tourism, etc. Hopefully, in the near future, visitors to Ba Ria -Vung Tau will no longer be disappointed with the poor tourism products here!

Tourism development has played an important role in the socio-economic development of Ba Ria-Vung Tau in recent years. In the future, with the orientation of developing tourism into a key economic sector, as well as developing Ba Ria-Vung Tau to become a tourism center of the Southeast region, requiring the tourism industry in Ba Ria-Vung Tau must build and develop in the direction of sustainable development. 
The research results show that social factors, tourism environment, technical facilities and tourism products are factors that strongly influence the sustainable development of tourism in Ba Ria-Vung Tau. This research results are consistent with the reality of Ba Ria-Vung Tau tourism industry. Therefore, through their research, the authors want to help the tourism industry in Ba Ria-Vung Tau determines the current situation, thereby having a scientific basis to assess the limitations and shortcomings to provide effective sustainable tourism development solutions. However, due to certain limitations in the data collection process, the number of samples and the study timespan, there are still shortcomings and limitations.

\section{References}

Angelevska-Najdeska, K., \& Rakicevik, G. (2012). Planning of sustainable tourism development. Procedia - Social and Behavioral Sciences, 44, 210-220. doi:10.1016/j. sbspro.2012.05.022.

Charter for Sustainable Tourism. (1995). Charter for Sustainable Tourism. UNWTO Declarations, 5(4), 1-16. Madrid, Spain: World Tourism Organization (UNWTO). DOI: 10.18111/ unwtodeclarations. 1995.05.04.

Fabić, M. M., \& Jurdana, D. S. (2018). Methodology of planning sustainable tourism development at the local level: Theory and practice. Congress Proceedings (pp. 260-272). Tourism \& Hospitality Industry.

IUCN-UNEP-WWF. (1980). World Conservation Strategy: Living Resource Conservation for Sustainable Development. Retrieved January 10, 2020 from: https://portals.iucn.org/library/efiles/ documents/wcs-004.pdf

Kattiyapornpong, U., Ditta-Apichai, M., Kanjanasilanon, C., \& Siriyota, K. (2018). Sustainable Tourism Development: An Application of Social Exchange Theory in Thailand. Asia Proceedings of Social Sciences, 2(3), 123-126.

Kim, M., Choi, K.-W., Chang, M., \& Lee, C.-H. (2020). Overtourism in Jeju Island: The Influencing Factors and Mediating Role of Quality of Life. Journal of Asian Finance, Economics and Business, 7(5), 145-154. doi:10.13106/jafeb.2020.vol7. no5.145.

Lee, J. W., \& Syah, A. M. (2018). Economic and Environmental Impacts of Mass Tourism on Regional Tourism Destinations in Indonesia. Journal of Asian Finance, Economics and Business, 5(3), 31-41. doi:10.13106/jafeb.2018.vol5.no3.31.

Liu, Z. (2003). Sustainable Tourism Development: A Critique. Journal of Sustainable Tourism, 11(6), 459-475. DOI: 09669582/03/06 0459-17 \$20.00/0.

Machado, A. (2003). Tourism and Sustainable Development. Capacity Building for Tourism Development in VietNam.
Vietnam: VNATF-UNDESO. Retrieved January 10, 2020 from: http:/www.antoniomachado.net/wp-content/uploads/ pdf/tourism/2003-tourism-and-sustainable-development.pdf

Maftuhah, D. I., \& Wirjodirdjo, B. (1977). Model for developing five key pillars of sustainable tourism: A literature review. AIP Conference Proceedings (pp. 1-15). https://doi. org/10.1063/1.5042979). AIP Publishing.

Mamhoori, A. (2015). Sustainable Tourism Development: An Empirical Survey of Tour Operators in India. Journal of Tourism \& Hospitality, 4(5), 1-6. DOI: 10.4172/2167-0269.1000183.

Mamhoori, A., \& Nasim, S. (2013). Sustainable Tourism Development in India: Analyzing the Role of Stakeholders. Proceedings of GLOGIFT, 13, 1078-1085.

Purnomo, S., Rahayu, E. S., Riani, A. L., Suminah, S., \& Udin, U. (2019). Empowerment Model for Sustainable Tourism Village in an Emerging Country. Journal of Asian Finance, Economics and Business, 7(2), 261-270. doi:10.13106/jafeb.2020.vo7. no2.261.

Rukuižienè, R. (2014). Sustainable tourism development implications to local economy. Regional Formation and Development Studies, 3(14), 170-177. DOI: http://dx.doi. org $/ 10.15181 /$ rfds.v14i3.873.

Setiawan, B., Rijanta, R., \& Baiquni, M. (2017). Sustainable Tourism Development: the Adaptation and Resilience of the Rural Communities in (the Tourist Villages of) Karimunjawa, Central Java. Forum Geografi, 31(2), 232-245. DOI: 10.23917/ forgeo.v31i2.5336.

UNEP. (2003). The Role of Local Authorities in Sustainable Tourism. Retrieved April 10, 2018 from: Tourism and Local Agenda 21: http://www.unep.fr/shared/publications/pdf/3207TourismAgenda.pdf

UNEP \& WTO. (2005). Making Tourism More Sustainable: A Guide for Policy Makers. Retrieved January 10, 2020 from: http://www.unep.fr/shared/publications/pdf/DTIx0592xPATourismPolicyEN.pdf

United Nations World Commission on Environment and Development. (1987). Report of the World Commission on Environment and Development: Our Common Future. Oxford, UK: Oxford University Press.

Vidishcheva, E. V., \& Bryukhanova, G. D. (2017). Analyses of the Sustainable Tourism Development Factors: the Example of Sochi-City. Journal of Advocacy, Research and Education 4(3), 172-180. http://kadint.net/our-journal.html.

Vodenska, M. (2020). Factors for (Un) Sustainable Tourism Development. Journal of Geography and Sustainable Development, 2(1), 16-29.

Vu, A. M., Nguyen, C. T., Nguyen, N. T., \& Le, T. (2020). Factors influencing on tourism sustainable development in Vietnam. Management Science Letters, 10, 1737-1742. DOI: 10.5267/j. msl.2020.1.006. 
Vuong, K. T., \& Rajagopal, P. (2019). Analyzing factors affecting tourism sustainable Development towards Vietnam in the new era. European Journal of Business and Innovation Research, 7(1), 30-42.

WCED. (1987). Our Common Future. Oxford, UK: Oxford University Press.
World Bank. (1999). Sustainable tourism and cultural heritage : a review of development assistance and its potential to promote sustainability. Washington DC: World Bank.

Zolfani, S. H., Sedaghat, M., Maknoon, R., \& Zavadskas, E. K. (2015). Sustainable tourism: a comprehensive literature review on frameworks and applications. Economic ResearchEkonomska Istraživanja, 28(1), 1-30. DOI: 10.1080/1. 